\title{
The investigation of immunomodulatory activities of Gloeostereum incaratum polysaccharides in cyclophosphamide-induced immunosuppression mice
}

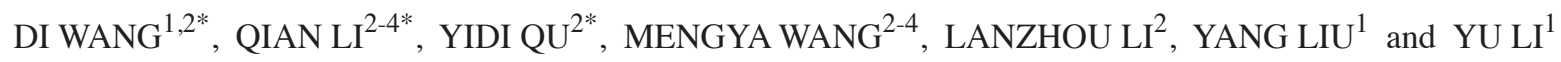 \\ ${ }^{1}$ Engineering Research Center of Chinese Ministry of Education for Edible and Medicinal Fungi, \\ Jilin Agricultural University, Changchun, Jilin 130118; ${ }^{2}$ School of Life Sciences, \\ Jilin University, Changchun, Jilin 130012; ${ }^{3}$ Department of Chemistry and Pharmacy, Zhuhai College of Jilin University; \\ ${ }^{4}$ Southern Research Institute, Jilin University, Zhuhai, Guangdong 519041, P.R. China
}

Received September 12, 2017; Accepted January 22, 2018

DOI: $10.3892 /$ etm.2018.5810

\begin{abstract}
Gloeostereum incarnatum, a precious edible mushroom, displays anti-bacterial and anti-inflammatory activities; however, its immunomodulatory effect has not been studied yet. The present study aimed to investigate whether polysaccharide compositions of $G$. incarnatum polysaccharides (GIPS) possess immunomodulatory and immuno-enhancing effects in a Cyclophosphamide monohydrate (CTX)-induced $\mathrm{BALB} / \mathrm{c}$ mice model. The 28-day GIPS administration at doses of $0.1,0.3$ and $0.9 \mathrm{~g} / \mathrm{kg}$ remarkably reversed the bodyweight loss, increased the thymic index and promoted $\mathrm{T}$ lymphocyte proliferation in CTX-induced immunosuppressed mice. GIPS significantly raised the serum levels of immunoglobulin (Ig) A and IgG, promoted the production of interleukins (ILs), including IL-2, IL-3 and IL-6, interferons, including interferon (IFN)- $\alpha$ and IFN- $\gamma$, and monocyte chemotactic protein 1 in the spleen, which resulted in accelerating recovery of immunosuppression. Finally, GIPS showed anti-oxidative effects indicated by the increased superoxide dismutase levels in the serum and spleen, and the reduced level of reactive oxygen species in the spleen. The results of the current study demonstrated that GIPS positively adjusts the immune system, which may serve as a potential immunostimulatory agent.
\end{abstract}

Correspondence to: Professor Yu Li, Engineering Research Center of Chinese Ministry of Education for Edible and Medicinal Fungi, Jilin Agricultural University, 2888 Xincheng Street, Changchun, Jilin 130118, P.R. China

E-mail: fungi966@163.com

${ }^{*}$ Contributed equally

Key words: Gloeostereum incaratum, immunomodulatory effect, polysaccharides, cyclophosphamide, oxidative stress

\section{Introduction}

The immune system, a complex self-regulation system, is responsible for the defense function of organism to prevent outside pathogens, remove the waste material and maintain the monitoring function for malignant cells (1). The immune system is highly sensitive (2), and shows impaired immune responsiveness to pathogen invasion, during which, immune cells are activated and secret pro-inflammatory mediators including interleukins (ILs) and interferons (INFs) are increased $(3,4)$. And immunity closely related to oxidative stress, which could lead to aberrant expression of inflammatory cytokines and chemokines (5). Cyclophosphamide monohydrate (CTX), a cancer chemotherapeutic agent, facilitates cell apoptosis and decreases the homeostatic proliferation of regulatory T cells (6), which has been widely used in the establishment of immunosuppressive animal models (7-9).

Previous researchers focus their studies on searching immunomodulatory agents for years (10). However, the drugs performed in clinic, especially single-component chemicals, display severe adverse effects including general malaise and/or neurotoxicity $(11,12)$, which is hard to meet the requirements of immunosuppressive patients. Dietary polysaccharides from natural products are getting more attention due to their health benefits and low toxicity $(13,14)$, which have been confirmed to exhibit multiple immunomodulatory effects $(15,16)$. Gloeostereum incarnatum, a precious edible mushroom, parasitizes broad-leaved wood in northern Japan and northern China (17). Traditionally, G. incarnatum preparation is widely used for the treatment for enteritis, dysentery and gastric ulcer (18). Polysaccharides obtained from G. incarnatum fruiting body have been reported to possess anti-tumor and anti-bacterial activities (17). However, the immunomodulatory effect of $G$. incarnatum has not been investigated yet.

The objective of this study aims to investigate whether polysaccharide compositions of $G$. incarnatum possess immunomodulatory and immuno-enhancing effects in a CTX-induced BALB/c mice model. Data demonstrated that $G$. incarnatum polysaccharides (GIPS) enhanced 
immunologic function in CTX-induced immunosuppressed mice by promoting the production of immune-associated factors in spleen, elevating serum immunoglobulin (Ig) levels, and restoring the imbalance of anti-oxidation and oxidation.

\section{Materials and methods}

GIPS preparation. G. incaratum fruiting body (Yunnan, China) was smashed and extracted with 20 -fold double distilled (D.D.) water at $90^{\circ} \mathrm{C}$ for $4 \mathrm{~h}$ twice. The water extracts were concentrated and deproteinated by Sevag agents (n-butanol:chloroform=1:4) (19). After centrifugation, the supernatant were collected, added 4-fold volume of ethanol, and placed at $4^{\circ} \mathrm{C}$ for overnight. The precipitation was dissolved in D.D. water and subjected to DEAE-52 cellulose anion exchange column $(2.6 \times 35 \mathrm{~cm})(20)$. The fractions (fraction 1 to 4 ) of crude GIPS were collected together, freeze dried and stored at $-80^{\circ} \mathrm{C}$. The detailed information can be found in Fig. 1A and B.

Protocols for immunosuppression mice development and agents administration. The experimental protocol was approved by Animal Ethics Committee in Jilin University (20160402). 72 of Balb/c male mice (8-week old, 18-20 g) [SCXK (JI)-2014-0003] were housed in cages with a $12 \mathrm{~h}$ light $/ 12 \mathrm{~h}$ dark period under a constant temperature $\left(23 \pm 2^{\circ} \mathrm{C}\right)$ and humidity-controlled conditions (50-60\%), and allowed free access to solid feed and tap water during the experiments.

After one-week acclimatization, mice were divided into six groups randomly as follows. Control group $(n=12)$ : 3-day normal saline injection following with 14-day normal saline gastric gavages. Cyclophosphamide (CTX)-injected group (model group; $\mathrm{n}=12)$ : 3 -day CTX $(75 \mathrm{mg} / \mathrm{kg}$; Sigma-Aldrich; Merck KGaA, Darmstadt, Germany) injection following with 14-day normal saline gastric gavages. GIPS-treated groups ( $\mathrm{n}=12 / \mathrm{group}): 3$-day CTX $(75 \mathrm{mg} / \mathrm{kg})$ injection following with 14-day GIPS $(0.1,0.3$ and $0.9 \mathrm{~g} / \mathrm{kg}$; dissolved in normal saline) gastric gavages. Thymosin $\alpha 1$ (Ta1) (positive drug)-treated group ( $\mathrm{n}=12)$ : 3 -day CTX $(75 \mathrm{mg} / \mathrm{kg})$ injection following with 14-day T $\alpha 1(0.16 \mathrm{mg} / \mathrm{kg}$; Jiangsu Hengrui Medicine Co., Ltd., Lianyungang, China) injection. General health and body weights of mice were monitored during the whole experimental period. At $24 \mathrm{~h}$ after the last administration, all mice were weighted, and killed. Blood and organs (spleen and thymus) were sampled immediately. The thymus index was calculated according to the formula: Index $(\mathrm{mg} / 10 \mathrm{~g})=($ Weight of thymus) $/ 10 \mathrm{x}$ (body weight).

Lymphocyte proliferation assay. Spleen of each mouse was aseptically removed and grounded into a single cell suspension (21), and seeded into a 96-well plate at density of $1 \times 10^{6} / 100 \mu 1$ mixed with $10 \mu 1$ of RPMI-1640 (Control group) or $10 \mu \mathrm{l}$ of $200 \mu \mathrm{g} / \mathrm{ml}$ concanavalin (ConA; Sigma-Aldrich; Merck KGaA). Then incubated under a humidified atmosphere containing $5 \% / 95 \% \mathrm{CO}_{2} /$ air at $37^{\circ} \mathrm{C}$ for $48 \mathrm{~h}$ similar as previous study (22), 3-(4,5-dimethylthiazol-2-yl)-2,5-diphenyltetrazolium bromide (MTT; Sigma-Aldrich; Merck $\mathrm{KGaA}$ ) assay were performed to analysis the changes of cell viability. The stimulation index (SI) of T lymphocyte transformation was calculated as following equation: $\mathrm{SI}=\mathrm{OD}_{490} \mathrm{ConA} / \mathrm{OD}_{490}$ control.

ELISA assay. The spleens were homogenized with D.D. water, and the protein concentrations were detected by a bicinchoninic acid protein assay kit (Merck KGaA). The levels of superoxide dismutase (SOD; 43125), ROS (43355), IgA (42791), IgG (42793) and IgM (42794) in serum and spleen, and the levels of ILs [IL-2 (42903), -3 (42902) and -6 (42912)], INFs [IFN- $\alpha$ (43102) and IFN- $\gamma$ (42918)] and monocyte chemotactic protein 1 (MCP-1; 42818) in spleen were detected by commercial ELISA kits (Shanghai Yuanye Bio-Technology Co., Ltd., Shanghai, China).

Statistical analysis. The statistical values are presented as the mean \pm standard error of the mean (SEM). Statistically comparisons were analyzed using a one-way analysis of variance (ANOVA) followed by Dunn's test via SPSS 16.0 software (IBM Corp., Armonk, NY, USA). P $<0.05$ was considered to indicate a statistically significant difference.

\section{Results}

Effects of GIPS on bodyweight, thymus index and lymphocyte proliferation. CTX strongly reduced the bodyweights of mice after 3-day injection $(\mathrm{P}<0.05$; Table I); in contrast, GIPS and T $\alpha 1$ improved the weight gain in immunosuppressed mice after 7-day administration $(\mathrm{P}<0.05$; Table I). Compared to normal mice, extremely low thymus index was observed in CTX-injected mice $(\mathrm{P}<0.001$; Table I). GIPS at doses of $0.1,0.3$ and $0.9 \mathrm{~g} / \mathrm{kg}$ and $\mathrm{T} \alpha 1$ at $0.16 \mathrm{mg} / \mathrm{kg}$ significantly enhanced the thymus index after 14-day treatment $(\mathrm{P}<0.05$; Table I).

Lymphocyte proliferation is commonly used to reflect the immune function (23). Compared to CTX-induced immunosuppressant mice, GIPS at $0.9 \mathrm{~g} / \mathrm{kg}$, but not T $\alpha 1$ promoted over $21.3 \% \mathrm{~T}$ lymphocyte proliferation ( $\mathrm{P}<0.05$; Fig. 2$)$.

GIPS enhanced immune globulin levels in the serum and spleen ofimmunosuppressed mice. CTX injection suppressed the levels of $\operatorname{Ig} \mathrm{A}$ and $\operatorname{IgG}$ in serum $(\mathrm{P}<0.01$; Fig. $3 \mathrm{~A}$ and $\mathrm{B})$, and reduced the levels of $\operatorname{IgG}$ and $\operatorname{IgM}$ in spleen $(\mathrm{P}<0.01$; Fig. 3B and C) of mice. Compared to CTX-induced immunosuppressant mice, $\mathrm{T} \alpha 1$ at $0.16 \mathrm{mg} / \mathrm{kg}$ significantly enhanced the levels of $\operatorname{Ig} \mathrm{A}, \operatorname{IgG}$ and $\operatorname{IgM}$ in serum $(\mathrm{P}<0.01$; Fig 3), and the levels of IgG in spleen ( $\mathrm{P}<0.01$; Fig. 2B). Differently, GIPS failed to increase the spleen levels of immune globulin in CTX-induced immunosuppressant mice (Fig. 3). In contrast, GIPS administration resulted in $>13.0 \%$ enhancement on IgA levels except for $0.1 \mathrm{~g} / \mathrm{kg}$ of GIPS ( $\mathrm{P}<0.001$; Fig $3 \mathrm{~A})$ and $>16.8 \%$ enhancement on IgG levels $(\mathrm{P}<0.05$; Fig $3 \mathrm{~B})$ in serum of CTX-induced immunosuppressant mice.

Effects of GIPS on immune factors in the spleen of immunosuppressed mice. Compared to normal mice, the levels of ILs (IL-2, -3 and -10), INFs (IFN- $\alpha$ and IFN- $\gamma$ ) and MCP-1 in spleen were significantly lowered in CTX-induced immunosuppressant mice $(\mathrm{P}<0.05$; Table II), which were all significantly restored by 14-day T $\alpha 1$ administration at $0.16 \mathrm{mg} / \mathrm{kg}(\mathrm{P}<0.05$; 
Table I. Regulatory effects of GIPS and T $\alpha 1$ on body weight and organ indexes.

\begin{tabular}{|c|c|c|c|c|c|c|}
\hline \multirow[b]{2}{*}{ Measurement } & \multirow[b]{2}{*}{ CTRL } & \multirow{2}{*}{$\begin{array}{c}\begin{array}{c}\text { CTX } \\
(\mathrm{mg} / \mathrm{kg})\end{array} \\
75\end{array}$} & \multicolumn{3}{|c|}{ GIPS (g/kg) } & \multirow{2}{*}{$\begin{array}{c}\begin{array}{c}\mathrm{T} \alpha 1 \\
(\mathrm{mg} / \mathrm{kg})\end{array} \\
0.16\end{array}$} \\
\hline & & & 0.1 & 0.3 & 0.9 & \\
\hline \multicolumn{7}{|l|}{ Body weight (g) } \\
\hline 1 st day & $26.4 \pm 0.4$ & $25.8 \pm 0.4$ & $27.1 \pm 0.3$ & $25.0 \pm 0.4$ & $27.4 \pm 0.6$ & $26.9 \pm 0.4$ \\
\hline 4th day & $25.8 \pm 0.3$ & $22.6 \pm 0.5^{\mathrm{a}}$ & $22.4 \pm 0.4$ & $22.8 \pm 0.7$ & $22.8 \pm 0.6$ & $22.5 \pm 0.4$ \\
\hline 11th day & $27.9 \pm 0.4$ & $24.6 \pm 0.3^{\mathrm{a}}$ & $25.6 \pm 0.5$ & $25.3 \pm 0.8$ & $26.9 \pm 0.5^{\mathrm{c}}$ & $24.8 \pm 0.6$ \\
\hline 18th day & $27.3 \pm 0.6$ & $23.1 \pm 0.4^{\mathrm{a}}$ & $25.1 \pm 0.2$ & $24.7 \pm 0.9$ & $26.0 \pm 0.8^{c}$ & $25.9 \pm 1.1^{\mathrm{c}}$ \\
\hline Thymus index $(\mathrm{mg} / 10 \mathrm{~g})$ & $0.23 \pm 0.02$ & $0.09 \pm 0.01^{\mathrm{b}}$ & $0.14 \pm 0.02^{\mathrm{d}}$ & $0.13 \pm 0.03^{c}$ & $0.17 \pm 0.03^{\mathrm{d}}$ & $0.15 \pm 0.03^{\mathrm{d}}$ \\
\hline
\end{tabular}

The changes of body weight were detected during the experimental period. After 14-day administration, thymus index was examined. Data were expressed as means \pm SEM ( $\mathrm{n}=12)$. ${ }^{\mathrm{a}} \mathrm{P}<0.05$ and ${ }^{\mathrm{b}} \mathrm{P}<0.001$ vs. control group, ${ }^{\mathrm{c}} \mathrm{P}<0.05$ and ${ }^{\mathrm{d}} \mathrm{P}<0.01$ vs. model group. CTX, Cyclophosphamide; GIPS, G. incarnatum polysaccharides; T $\alpha 1$, Thymosin $\alpha 1$; CTRL, control.

A

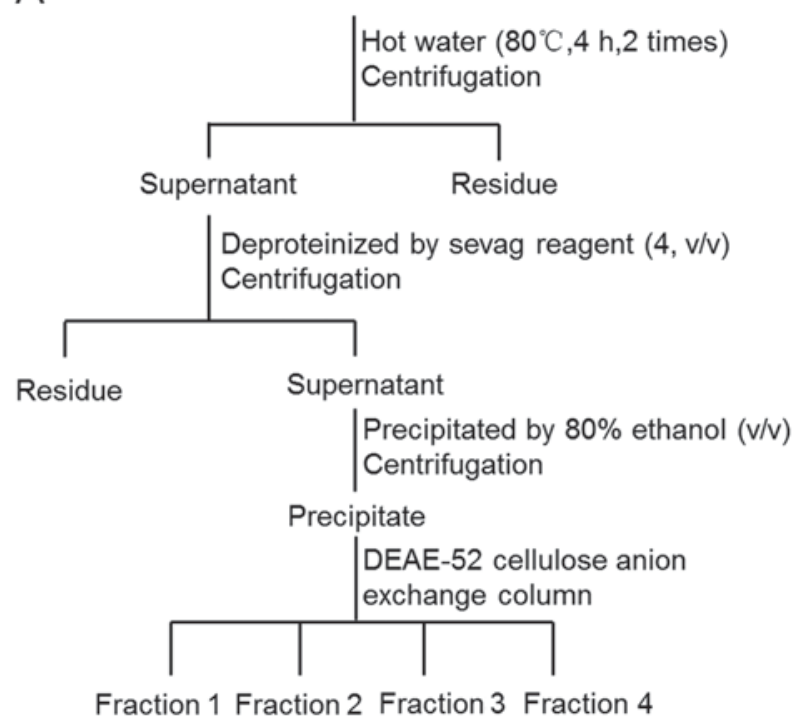

B

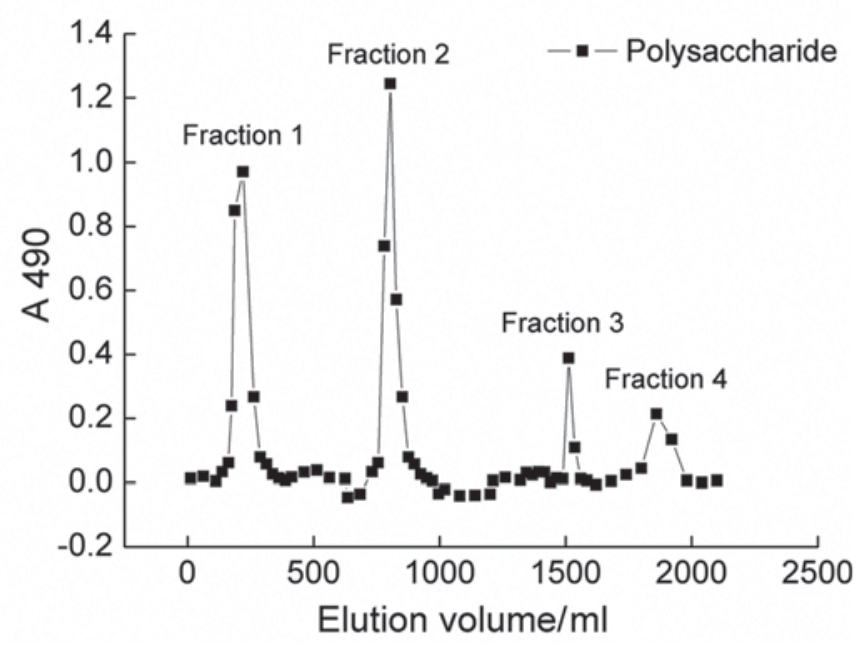

Figure 1. (A) The Scheme for extraction and isolation of polysaccharides from G. incarnatum. (B) DEAE-Sepharose fast flow chromatogram of the crude polysaccharides.

Table II). GIPS, especially at $0.9 \mathrm{~g} / \mathrm{kg}$, increase $191.1 \%$ of IL-2 $(\mathrm{P}<0.01), 94.7 \%$ of IL-3 $(\mathrm{P}<0.01), 136.1 \%$ of IL-6 $(\mathrm{P}<0.001)$, $68.7 \%$ of IFN- $\alpha(\mathrm{P}<0.05), 50.6 \%$ of IFN- $\gamma(\mathrm{P}<0.05)$, and $77.8 \%$ of MCP-1 $(\mathrm{P}<0.001)$ in spleen compared to CTX-injected mice (Table II).

Effects of GIPS on the oxidative stress factors in serum and spleen of immunosuppressed mice. Compared to normal mice, CTX injection strongly reduced the levels of SOD in serum and spleen $(\mathrm{P}<0.001$; Table III), but failed to significantly influence ROS levels (Table III). T $\alpha 1$ only enhanced the levels of SOD $(\mathrm{P}<0.01$; Table III), but not ROS, in serum and spleen of CTX-injected mice. Compared to immunosuppressed mice, 14-day GIPS administration resulted in $>14.6 \%$ and $>51.5 \%$ enhancement on SOD levels in serum (except for $0.1 \mathrm{~g} / \mathrm{kg}$ GIPS) and spleen, respectively $(\mathrm{P}<0.05$; Table III). GIPS showed no effects on serum ROS levels (Table III); in contrast, GIPS at doses of 0.3 and $0.9 \mathrm{~g} / \mathrm{kg}$ significantly reduced the levels of ROS in spleen compared to immunosuppressed mice $(\mathrm{P}<0.01$; Table III).

\section{Discussion}

In this study, we evaluated the immunoregulation effect of GIPS in CTX-induced immunosuppressed mice, and this model is recognized as a well characterized model. There are reports that, CTX shows immunosuppressive effect mainly through lymphocytes toxicity via disturbing DNA and RNA function $(24,25)$. GIPS significantly reversed the atrophy of immune organs, especially thymus, and enhanced T lymphocyte proliferation. Spleen, an important immune organ, is the primary site for the development of T cells and B cells (26). The proliferation of $\mathrm{T}$ and $\mathrm{B}$ lymphocytes in response to microbial antigen is known as a typical non-specific immune 


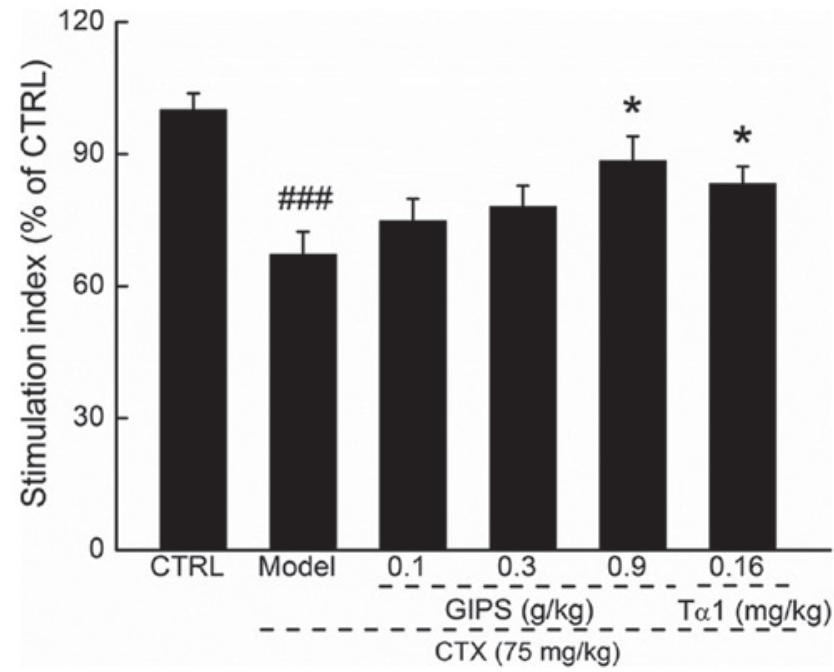

Figure 2. GIPS enhanced the lymphocyte proliferation of spleen in CTX-induced immunosuppressed mice. Data were expressed as means \pm SEM $(n=12) .{ }^{\# \# \#} \mathrm{P}<0.001$ vs. control group, ${ }^{*} \mathrm{P}<0.05$ vs. model group. CTX, Cyclophosphamide; GIPS, G. incarnatum polysaccharides; T $\alpha 1$, Thymosin $\alpha 1$.

reaction. Thus, the determination of lymphocyte proliferation can reflect the immune status (23). Moreover, GIPS increased the serum Ig levels in CTX-induced immunosuppressed mice. Ig is the crucial component of organism immune system and plays a vital role in immune function (27). IgG is found to be the most abundant Igs and mediates natural passive immunity including antibacterial, antivirus and antitoxin (28); meanwhile, IgA shows bacteriolysis and promotive function in phagocytosis and aggregation (29). Immuno-stimulants, such as bacterial antigen lysate, significantly enhanced $\operatorname{Ig} G$ and $\operatorname{Ig} A$ serum levels in children with recurrent infections $(30,31)$. IgM, one of the largest molecular weight Ig, accounts or 5-10\% of the total serum Ig, which appears firstly in the humoral immune response of antibodies (32). The detection of serum IgM levels serves as an index of the early diagnosis of infection. Altogether, we successfully confirmed the immunoregulation activities of GIPS in the CTX-induced immunosuppressed mouse model.

GIPS successfully regulated the levels of ILs, INFs and MCP-1 in spleen of CTX-induced immunosuppressed mice. The immune response targets various cytokines, some of which directly influence immunity of organs. T helper (Th) cells, one of subsets of $\mathrm{T}$ cells, mediates the production of ILs, which can active immune cells during immune response evidencing by huper-levels of IL-2 activates pro-inflammatory $\mathrm{CD}^{+} \mathrm{T}$ cells (33). IL-3 participates in regulating myeloid cell expansion, autoimmunity and modulate human $\mathrm{CD} 4^{+}$monocyte response in short-term or long-term models of trained immunity (34). IL-6 is a critical factor for maturation, proliferation, differentiation and maintenance of B cells/plasma cells, which seems to enhance the development of pro-inflammatory cell and to inhibit the development T regulatory cells (35). IL-6 promotes the expression of IL-2 in T cells, which further interacts with IL-3 to promote the differentiation of T cells (36). Moreover, Th1 cells secretes IFN- $\alpha$ and IFN- $\gamma$, which promotes cytotoxic lymphocytes formation and activity of macrophage $(37,38)$. IFN- $\gamma$, an
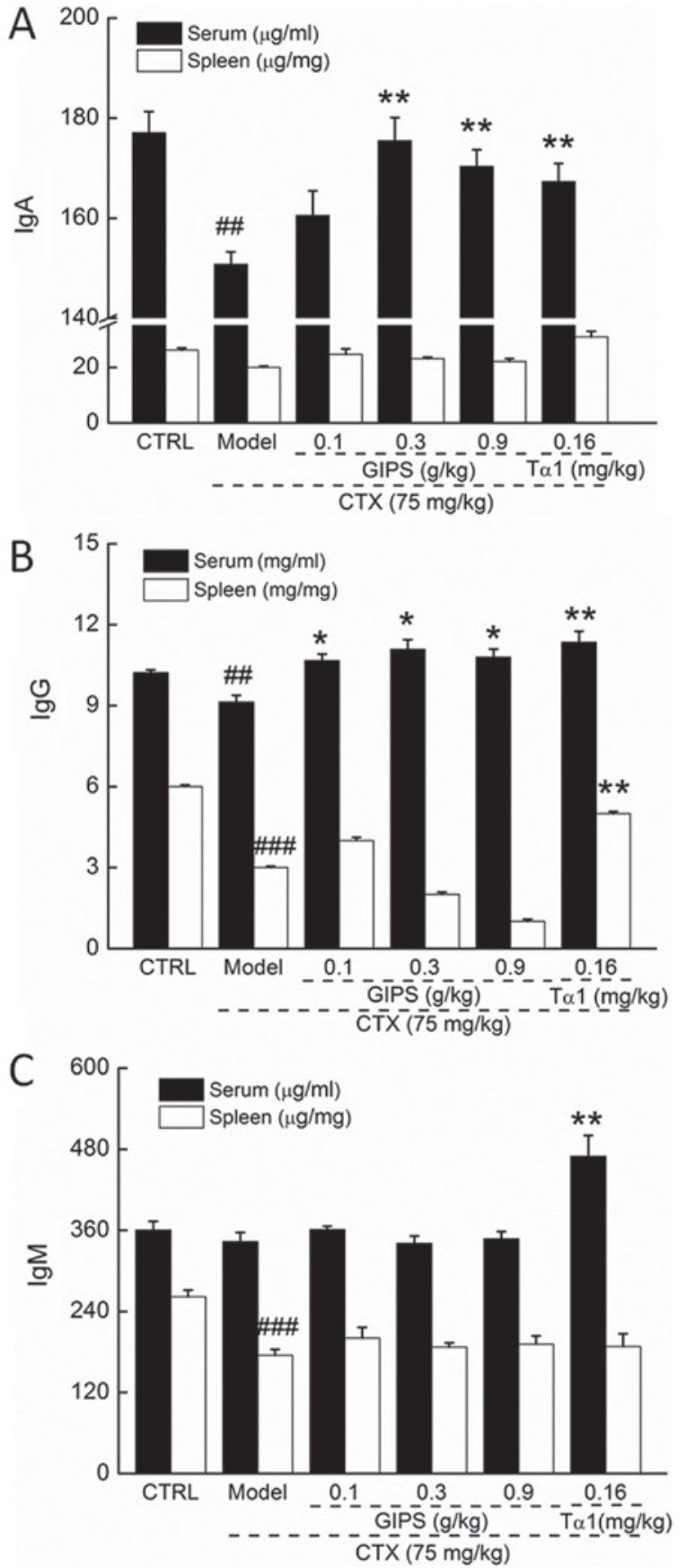

Figure 3. The regulatory effects of GIPS $(0.1,0.3$ and $0.9 \mathrm{~g} / \mathrm{kg})$ and Ta1 $(0.16 \mathrm{mg} / \mathrm{kg}$ ) on the levels of (A) $\operatorname{IgA}$, (B) $\operatorname{IgG}$ and (C) $\operatorname{IgM}$ in serum and spleen of CTX-induced immunosuppressed mice. Data were expressed as means \pm SEM $(n=12) .{ }^{* \# \#} \mathrm{P}<0.01$ and ${ }^{\# \# \# \#} \mathrm{P}<0.001$ vs. control group, ${ }^{*} \mathrm{P}<0.05$ and ${ }^{* *} \mathrm{P}<0.01$ vs. model group. CTX, Cyclophosphamide; GIPS, G. incarnatum polysaccharides; T $\alpha 1$, Thymosin $\alpha 1$.

essential cytokine for host defense against pathogens, can stimulate macrophages to eliminate bacterial and tumor cell, activate neutrophil and natural killer (NK) cell (37). GIPS significantly enhanced the levels of MCP-1 in spleen of CTX-induced immunosuppressed mice. MCP-1, a member of the CC chemokine family, is responsible for recruiting monocytes, $\mathrm{T}$ cells and dendritic cells to inflammatory sites caused by infection (39). All the data obtained in our present experiment further confirmed the immunoregulation activities of GIPS in CTX-induced immunosuppressed mice. 
Table II. Regulatory effects of GIPS and T $\alpha 1$ on interleukins, interferons and MCP-1 in spleen of CTX-induced immunosuppressed mice.

\begin{tabular}{|c|c|c|c|c|c|c|}
\hline \multirow[b]{2}{*}{ Protein } & \multirow[b]{2}{*}{ CTRL } & \multirow[b]{2}{*}{ Model } & \multicolumn{3}{|c|}{ GIPS (g/kg) } & \multirow{2}{*}{$\frac{\begin{array}{c}\mathrm{T} \alpha 1 \\
(\mathrm{mg} / \mathrm{kg})\end{array}}{0.16}$} \\
\hline & & & 0.1 & 0.3 & 0.9 & \\
\hline IL-2 (pg/mg) & $21.2 \pm 1.0$ & $6.7 \pm 0.8^{b}$ & $9.0 \pm 0.4$ & $9.5 \pm 1.0$ & $19.5 \pm 4.0^{\mathrm{d}}$ & $12.0 \pm 0.7^{\mathrm{c}}$ \\
\hline IL-3 (pg/mg) & $6.4 \pm 0.37$ & $3.8 \pm 0.4^{\mathrm{a}}$ & $4.7 \pm 0.5$ & $5.2 \pm 0.4$ & $7.4 \pm 1.3^{\mathrm{d}}$ & $6.0 \pm 0.7^{c}$ \\
\hline IL-6 (pg/mg) & $9.7 \pm 0.7$ & $3.6 \pm 0.5^{\mathrm{b}}$ & $5.7 \pm 0.4$ & $6.6 \pm 0.6^{c}$ & $8.5 \pm 1.1^{\mathrm{e}}$ & $7.2 \pm 0.7^{d}$ \\
\hline IFN- $\alpha(\mathrm{pg} / \mathrm{mg})$ & $2.6 \pm 0.2$ & $1.6 \pm 0.1^{\mathrm{a}}$ & $2.4 \pm 0.1$ & $2.6 \pm 0.3$ & $2.7 \pm 0.1^{\mathrm{c}}$ & $3.6 \pm 0.5^{\mathrm{d}}$ \\
\hline IFN- $\gamma(\mathrm{pg} / \mathrm{mg})$ & $15.4 \pm 0.8$ & $7.9 \pm 0.6^{\mathrm{b}}$ & $9.5 \pm 0.8$ & $9.2 \pm 0.5$ & $11.9 \pm 1.3^{\mathrm{c}}$ & $12.4 \pm 1.2^{\mathrm{d}}$ \\
\hline MCP-1 (pg/mg) & $1.3 \pm 0.1$ & $0.9 \pm 0.1^{b}$ & $1.2 \pm 0.1^{\mathrm{d}}$ & $1.5 \pm 0.1^{\mathrm{e}}$ & $1.6 \pm 0.1^{\mathrm{e}}$ & $1.3 \pm 0.1^{\mathrm{d}}$ \\
\hline
\end{tabular}

Data were expressed as means \pm SEM $(\mathrm{n}=12)$. ${ }^{\mathrm{a}} \mathrm{P}<0.05$ and ${ }^{\mathrm{b}} \mathrm{P}<0.001$ vs. control group, ${ }^{\mathrm{c}} \mathrm{P}<0.05,{ }^{\mathrm{d}} \mathrm{P}<0.01$ and ${ }^{\mathrm{e}} \mathrm{P}<0.001$ vs. model group. CTX, Cyclophosphamide; GIPS, G. incarnatum polysaccharides; T $\alpha 1$, Thymosin $\alpha 1$; CTRL, control; IL, interleukin; IFN, interferon; MCP, monocyte chemotactic protein.

Table III. Regulatory effects of GIPS and T $\alpha 1$ on the levels of SOD and ROS in serum and spleen of CTX-induced immunosuppressed mice.

\begin{tabular}{|c|c|c|c|c|c|c|}
\hline \multirow[b]{2}{*}{ Group } & \multirow[b]{2}{*}{ CTRL } & \multirow[b]{2}{*}{ Model } & \multicolumn{3}{|c|}{ GIPS (g/kg) } & \multirow{2}{*}{$\begin{array}{c}\begin{array}{c}\mathrm{T} \alpha 1 \\
(\mathrm{mg} / \mathrm{kg})\end{array} \\
0.16\end{array}$} \\
\hline & & & 0.1 & 0.3 & 0.9 & \\
\hline \multicolumn{7}{|l|}{ Serum } \\
\hline $\mathrm{SOD}(\mathrm{U} / \mathrm{ml})$ & $150.5 \pm 6.1$ & $113.3 \pm 4.0^{\mathrm{a}}$ & $119.0 \pm 3.1$ & $129.8 \pm 1.6^{\mathrm{b}}$ & $136.8 \pm 3.9^{c}$ & $138.0 \pm 3.1^{\mathrm{c}}$ \\
\hline ROS (U/ml) & $32.6 \pm 0.6$ & $33.3 \pm 0.6$ & $32.0 \pm 1.0$ & $31.75 \pm 1.6$ & $31.2 \pm 1.4$ & $34.1 \pm 1.0$ \\
\hline \multicolumn{7}{|l|}{ Spleen } \\
\hline $\mathrm{SOD}(\mathrm{U} / \mathrm{mg})$ & $30.5 \pm 2.2$ & $16.5 \pm 1.2^{\mathrm{a}}$ & $25.0 \pm 2.3^{b}$ & $26.1 \pm 0.6^{\mathrm{b}}$ & $27.8 \pm 2.5^{\mathrm{c}}$ & $32.4 \pm 2.1^{\mathrm{c}}$ \\
\hline ROS (U/mg) & $39.8 \pm 2.7$ & $42.7 \pm 7.1$ & $30.7 \pm 1.9$ & $28.2 \pm 2.9^{\mathrm{b}}$ & $23.1 \pm 2.4^{\mathrm{c}}$ & $30.4 \pm 2.9$ \\
\hline
\end{tabular}

Data were expressed as means $\pm \mathrm{SEM}(\mathrm{n}=12)$. ${ }^{\mathrm{a}} \mathrm{P}<0.001$ vs. control group, ${ }^{\mathrm{b}} \mathrm{P}<0.05,{ }^{\mathrm{c}} \mathrm{P}<0.01$ and ${ }^{\mathrm{d}} \mathrm{P}<0.001$ vs. model group. CTX, Cyclophosphamide; GIPS, G. incarnatum polysaccharides; T $\alpha 1$, Thymosin $\alpha 1$; CTRL, control; SOD, superoxide dismutase; ROS, reactive oxygen species.

On the other hand, ooxidative stress is identified as one of the pathogenic factor of the immune system in inflammatory diseases (40), which has an effect on human $\mathrm{T}$ cell differentiation and polarization (41). The immune cell functions are mainly associated with the imbalance of the antioxidant/oxidant, especially the over-generation of ROS (42). Therefore, it is beneficial to prevent the injury of immune cells and maintain normal immune system function with adequate amounts of antioxidants (43). The balance between production and consumption of ROS is a key factor that determines the the physiological activities and function of $\mathrm{T}$ cells (44). SOD, the endogenous anti-oxidant, is the recognized as the first line of defense of oxidative stress, especially helping to scavenging ROS (45). GIPSsignificantly enhanced the levels of SOD in serum and spleen, and reduced the levels of ROS in spleen of CTX-induced immunosuppressed mice. However, more experiments need to be performed to investigate the roles of anti-oxidation of GIPS during its immunoregulation effects.

To our knowledge, we first confirmed the immunomodulatory effects of $G$. incaratum in the CTX-induced immunosuppressed mouse model, and provided the experimental evidence for the use of GIPS as a potential immunostimulatory agent. Although we found that GIPS can regulate the levels of ILs, INFs and oxidative stress factors, the underlying mechanism still need further investigation.

\section{Acknowledgements}

This study was supported by Science and Technology Key Project in Jilin Province of China (nos. 20160520036JH and 20160204029YY), China Postdoctoral Science Foundation (no. 2016M591495) and the Special Projects of Cooperation between Jilin University and Jilin Province (grant no. SXGJSF2017-1). 


\section{References}

1. Loh L, Wang ZF, Sant S, Koutsakos M, Jegaskanda S, Corbett AJ, Liu L, Fairlie DP, Crowe J, Rossjohn J, et al: Human mucosal-associated invariant $\mathrm{T}$ cells contribute to antiviral influenza immunity via IL-18-dependent activation. Proc Natl Acad Sci USA 113: 10133-10138, 2016.

2. Collopy KT, Kivlehan SM and Snyder SR: The impaired immune system. How is it suppressed and what does it mean for EMS? EMS World 42: 115-118, 2013

3. Yoshimura A, Suzuki M, Sakaguchi R, Hanada T and Yasukawa H: SOCS, inflammation and autoimmunity. Front Immunol 3: 20, 2012.

4. Ferlazzo G, Tsang ML, Moretta L, Melioli G, Steinman RM and Münz C: Human dendritic cells activate resting natural killer (NK) cells and are recognized via the NKp30 receptor by activated NK cells. J Exp Med 195: 343-351, 2002.

5. Reuter S, Gupta SC, Chaturvedi MM and Aggarwal BB Oxidative stress, inflammation, and cancer: How are they linked? Free Radic Biol Med 49: 1603-1616, 2010.

6. Goldstein M, Roos WP and Kaina B: Apoptotic death induced by the cyclophosphamide analogue mafosfamide in human lymphoblastoid cells: Contribution of DNA replication, transcription inhibition and Chk/p53 signaling. Toxicol Appl Pharmacol 229: 20-32, 2008

7. Frey BM: Mechanism of action of immunosuppressive agents. Ther Umsch 50: 71-76, 1993 (In German).

8. Gassmann W, Uharek L, Wottge HU, Schmitz N, Löffler H and Mueller-Ruchholtz W: Comparison of cyclophosphamide, cytarabine, and etoposide as immunosuppressive agents before allogeneic bone marrow transplantation. Blood 72: 1574-1579, 1988.

9. Fan Y, Ma L, Zhang W, Xu Y, Suolangzhaxi, Zhi X, Cui E and Song X: Microemulsion can improve the immune-enhancing activity of propolis flavonoid on immunosuppression and immune response. Int J Biol Macromol 63: 126-132, 2014.

10. Gao HY, Li GY, Huang J, Han Y, Sun FZ, Du XW, An LJ, Wang $\mathrm{HY}$ and Wang JH: Protective effects of Zhuyeqing liquor on the immune function of normal and immunosuppressed mice in vivo. BMC Complement Altern Med 13: 252, 2013.

11. Płonka PM: Hair pigmentation disorders or 50 years of German-Polish alliance for study on a severe side effect of chemotherapy: Kostanecki's legacy. Exp Dermatol 24: 10-11, 2015.

12. Markman M: Chemotherapy-associated neurotoxicity: An important side effect-impacting on quality, rather than quantity, of life. J Cancer Res Clin Oncol 122: 511-512, 1996.

13. Ren L, Perera $C$ and Hemar Y: Antitumor activity of mushroom polysaccharides: A review. Food Funct 3: 1118-1130, 2012.

14. Ben Jeddou K, Chaari F, Maktouf S, Nouri-Ellouz O, Helbert CB and Ghorbel RE: Structural, functional, and antioxidant properties of water-soluble polysaccharides from potatoes peels. Food Chem 205: 97-105, 2016.

15. Zhou L, Liu Z, Wang Z, Yu S, Long T, Zhou X and Bao Y: Astragalus polysaccharides exerts immunomodulatory effects via TLR4-mediated MyD88-dependent signaling pathway in vitro and in vivo. Sci Rep 7: 44822, 2017.

16. Zheng Y, Wang Q, Zhuang W, Lu X, Miron A, Chai TT, Zheng B and Xiao J: Cytotoxic, antitumor and immunomodulatory effects of the water-soluble polysaccharides from lotus (Nelumbo nucifera Gaertn.) seeds. Molecules 21: pii: E1465, 2016.

17. Asai R, Mitsuhashi S, Shigetomi K, Miyamoto T and Ubukata M: Absolute configurations of (-)-hirsutanol A and (-)-hirsutanol C produced by Gloeostereum incarnatum. J Antibiot (Tokyo) 64 693-696, 2011

18. Bunbamrung N, Intaraudom C, Dramae A, Boonyuen N, Veeranondha S, Rachtawee $\mathrm{P}$ and Pittayakhajonwut P: Antimicrobial activity of illudalane and alliacane sesquiterpenes from the mushroom Gloeostereum incarnatum BCC41461. Phytochem Lett 20: 274-281, 2017.

19. Yan H, Zhu D, Xu D, Wu J and Bian X: A study on Cordyceps militaris polysaccharide purification, composition and activity analysis. Afr J Biotechnol 7: 4004-4009, 2008.

20. Zhang AL, Lu Jh, Zhang N, Zheng D, Zhang GR and Teng LR Extraction, purification and anti-tumor activity of polysaccharide from mycelium of mutant cordyceps militaris. Chem Res Chin Univ 26: 798-802, 2010

21. Jia D, Lu W, Wang C, Sun S, Cai G, Li Y, Wang G, Liu Y, Zhang M and Wang D: Investigation on immunomodulatory activity of calf spleen extractive injection in cyclophosphamide-induced immunosuppressed mice and underlying mechanisms. Scand J Immunol 84: 20-27, 2016
22. Roehm NW, Rodgers GH, Hatfield SM and Glasebrook AL: An improved colorimetric assay for cell proliferation and viability utilizing the tetrazolium salt XTT. J Immunol Methods 142: 257-265, 1991.

23. Cho CW, Han CJ, Rhee YK, Lee YC, Shin KS, Shin JS, Lee KT and Hong HD: Cheonggukjang polysaccharides enhance immune activities and prevent cyclophosphamide-induced immunosuppression. Int J Biol Macromol 72: 519-525, 2015.

24. Misra RR and Bloom SE: Roles of dosage, pharmacokinetics, and cellular sensitivity to damage in the selective toxicity of cyclophosphamide towards B and $\mathrm{T}$ cells in development. Toxicology 66: 239-256, 1991.

25. Fraiser LH, Kanekal S and Kehrer JP: Cyclophosphamide toxicity. Characterising and avoiding the problem. Drugs 42: 781-795, 1991.

26. Kuwana M, Okazaki Y, Kaburaki J, Kawakami Y and Ikeda Y: Spleen is a primary site for activation of platelet-reactive $\mathrm{T}$ and $B$ cells in patients with immune thrombocytopenic purpura. J Immunol 168: 3675-3682, 2002.

27. Clem LW and Small PA Jr: Phylogeny of immunoglobulin structure and function. V. Valences and association constants of teleost antibodies to a haptenic determinant. J Exp Med 132: 385-400, 1970

28. Quast I, Peschke B and Lünemann JD: Regulation of antibody effector functions through IgG Fc N-glycosylation. Cell Mol Life Sci 74: 837-847, 2017.

29. Herich R: Is the role of IgA in local immunity completely known? Food Agric Immunol 28: 1-15, 2016

30. Sanad MM and Al-Furaeihi LM: Effect of some immunomodulators on the host-parasite system in experimental Hymenolepiasis nana. J Egypt Soc Parasitol 36: 65-80, 2006.

31. Quezada A, Maggi L, Pèrez MA and Rodríguez J: Effect of bacterial antigen lysate on IgG and IgA levels in children with recurrent infections and hypogammaglobulinemia. J Investig Allergol Clin Immunol 9: 178-182, 1999.

32. Maverakis E, Kim K, Shimoda M, Gershwin ME, Patel F, Wilken R, Raychaudhuri S, Ruhaak LR and Lebrilla CB: Glycans in the immune system and the altered glycan theory of autoimmunity: A critical review. J Autoimmun 57: 1-13, 2015.

33. Zhu J, Yamane H and Paul WE: Differentiation of effector CD4 T cell populations (*). Annu Rev Immunol 28: 445-489, 2010.

34. Borriello F, Iannone R, Di Somma S, Loffredo S, Scamardella E, Galdiero MR, Varricchi G, Granata F, Portella G and Marone G: GM-CSF and IL-3 modulate human monocyte TNF- $\alpha$ production and renewal inin vitromodels of trained immunity. Front Immunol 7: 680, 2016

35. Tvedt THA, Ersvaer E, Tveita AA and Bruserud Ø: Interleukin-6 in allogeneic stem cell transplantation: Its possible importance for immunoregulation and as a therapeutic target. Front Immunol 8: $667,2017$.

36. Dienz O and Rincon M: The effects of IL-6 on CD4 T cell responses. Clin Immunol 130: 27-33, 2009.

37. Cope A, Le Friec G, Cardone J and Kemper C: The Th1 life cycle: Molecular control of IFN- $\gamma$ to IL-10 switching. Trends Immunol 32: 278-286, 2011

38. Ma JJ, Yang BY, Yu SF, Zhang Y, Zhang X, Lao S, Chen X, Li B and Wu C: Tuberculosis antigen-induced expression of IFN- $\alpha$ in tuberculosis patients inhibits production of IL-1 $\beta$. Faseb J 28: 3238-3248, 2014

39. Xu LL, Warren MK, Rose WL, Gong W and Wang JM: Human recombinant monocyte chemotactic protein and other $\mathrm{C}-\mathrm{C}$ chemokines bind and induce directional migration of dendritic cells in vitro. J Leukoc Biol 60: 365-371, 1996.

40. Egea J,Fabregat I, Frapart YM, Ghezzi P, Görlach A, Kietzmann T, Kubaichuk K, Knaus UG, Lopez MG, Olaso-Gonzalez G, et al: European contribution to the study of ROS: A summary of the findings and prospects for the future from the COST action BM1203 (EU-ROS). Redox Biol 13: 94-162, 2017.

41. King MR, Ismail AS, Davis LS and Karp DR: Oxidative stress promotes, polarization of human $\mathrm{T}$ cell differentiation toward a $\mathrm{T}$ helper 2 phenotype. J Immunol 176: 2765-2772, 2006.

42. De la Fuente M: Effects of antioxidants on immune system ageing. Eur J Clin Nutr 56 (Suppl 3): S5-S8, 2002.

43. Gutteridge JM and Mitchell J: Redox imbalance in the critically ill. Br Med Bull 55: 49-75, 1999.

44. Chen X, Song M, Zhang B and Zhang Y: Reactive oxygen species regulate $\mathrm{T}$ cell immune response in the tumor microenvironment. Oxid Med Cell Longev 2016: 1580967, 2016.

45. Islam MT: Oxidative stress and mitochondrial dysfunction-linked neurodegenerative disorders. Neurol Res 39: 73-82, 2017. 